\title{
PLANTING TIMES AND SPACING OF CARROT CROPS IN THE SÃO FRANCISCO VALLEY, PERNAMBUCO STATE, BRAZIL ${ }^{1}$
}

\author{
GERALDO MILANEZ DE RESENDE ${ }^{2 *}$, JONY EISHI YURI ${ }^{2}$, NIVALDO DUARTE COSTA ${ }^{2}$
}

\begin{abstract}
Climate variations over the year and plant density tend to strongly affect the agronomic performance of carrot crops. Thus, the objective of this work was to evaluate the performance of the cultivar Brasilia in crops under mild (winter) and high (summer) temperatures. An experiment was conducted from May 2011 to February 2012, using a randomized block design and treatments arranged in split plot, with three replications. The plots consisted of planting seasons (winter and summer) and the subplots of plant spacing (4, 6,8 and $10 \mathrm{~cm}$ ). The height of plants presented a linear decrease, from 53.4 to $51.0 \mathrm{~cm}$, with an increase in spacing in summer planting, while in winter the greatest height $(50.7 \mathrm{~cm})$ was obtained with spacing of $8.0 \mathrm{~cm}$ between plants. The lowest commercial yields were found in summer crops and with the widest spacing between plants. The smallest spacing between plants $(4 \mathrm{~cm})$ had yields of $45.9 \mathrm{Mg} \mathrm{ha}^{-1}$ in summer and of 63.1 $\mathrm{Mg} \mathrm{ha}^{-1}$ in winter crops. The winter planting had higher fresh root weight $\left(89.9 \mathrm{~g} \mathrm{root}^{-1}\right)$ compared to the summer $\left(81.4 \mathrm{~g} \mathrm{root}^{-1}\right)$, reaching higher weight with increasing plant spacing. Higher yields are achieved with plant spacing of $4 \mathrm{~cm}$ during winter. The carrot can be grown throughout the year in the Submiddle of the São Francisco Valley.
\end{abstract}

Keywords: Daucus carota. Yield. Planting density. Summer. Winter.

\section{ÉPOCAS DE PLANTIO E ESPAÇAMENTOS ENTRE PLANTAS NA CULTURA DA CENOURA CULTIVADAS NO SUBMÉDIO DO VALE DO SÃO FRANCISCO}

\begin{abstract}
RESUMO - As variações climáticas ao longo do ano e a densidade de plantas tendem a influenciar de forma acentuada o desempenho agronômico da cultura da cenoura. Com o objetivo de avaliar o desempenho produtivo da cultivar Brasília em cultivo sob temperaturas amenas (inverno) e mais elevadas (verão) conduziuse um experimento no período de maio de 2011 a fevereiro de 2012. Utilizou-se o delineamento de blocos casualizados, sendo os tratamentos dispostos em parcelas subdivididas, com três repetições. A parcela foi constituída pelas épocas de plantio (inverno e verão) e as subparcelas pelos espaçamentos entre plantas (4, 6, 8 e $10 \mathrm{~cm}$ ), sendo utilizada a cultivar Brasília. A altura de plantas apresentou redução linear com o aumento do espaçamento no cultivo de verão de 53,4 para $51,0 \mathrm{~cm}$, enquanto no inverno a maior altura foi obtida no espaçamento de $8 \mathrm{~cm}$ entre plantas com $50,7 \mathrm{~cm}$. Menor produtividade comercial foi obtida no cultivo de verão e nos maiores espaçamentos. O menor espaçamento de $4 \mathrm{~cm}$ entre plantas obteve nos cultivos de verão e inverno produtividades de 45,9 e 63,1 t ha ${ }^{-1}$, respectivamente. Com relação à massa fresca de raiz o plantio de inverno mostrou-se superior com maior massa fresca de raiz $\left(89,9 \mathrm{~g}\right.$ raiz $\left.^{-1}\right)$ comparativamente ao verão que alcançou $81,4 \mathrm{~g} \mathrm{raiz}^{-1}$, observando-se maior massa com o aumento do espaçamento entre plantas. Maiores produtividades são alcançadas no espaçamento de $4 \mathrm{~cm}$ entre plantas, em condições de inverno, podendo a cenoura ser cultivada durante todo o ano nas condições do Submédio do Vale do São Francisco.
\end{abstract}

Palavras-chave: Daucus carota. Produtividade. Densidade de Plantio. Verão. Inverno.

\footnotetext{
*Corresponding author

${ }^{1}$ Received for publication in 11/12/2014; accepted in 03/24/2016.

${ }^{2}$ Centro de Pesquisa Agropecuária do Trópico Semiárido, Petrolina, PE, Brazil; geraldo.milanez@embrapa.br, jony.yuri@embrapa.br, nivaldo.costa@embrapa.br.
} 


\section{INTRODUCTION}

The carrot (Daucus carota L.) is the fifth most economically important vegetable grown in Brazil (MAROUELLI et al., 2007). Among the vegetables whose edible parts are the root, the carrot has the most economic value; it presents high vitamin A content, soft texture and pleasant taste (FILGUEIRA, 2008). Moreover, it stands out by generating jobs and income throughout its production chain all year (VILELA; BORGES, 2008).

The domestic production of carrot in 2012 was $780,500 \mathrm{Mg}$, cropped on an area of 26,500 hectares, with average yield of $29.4 \mathrm{Mg} \mathrm{ha}^{-1}$ (EMBRAPA HORTALIÇAS, 2014). The world production in the same year was 36.9 million $\mathrm{Mg}$, cropped in an area of 1.19 million hectares, with average yield of $31.0 \mathrm{Mg} \mathrm{ha}^{-1}$ (FAO, 2014).

Carrots can be grown all the year round in Brazil, which has specific cultivars for fall-winter, spring and summer. However, summer crops undergo various climatic conditions that may adversely affect seed germination and plant development due to high temperatures (RESENDE et al., 2005), resulting in low yield and quality of roots. Summer is considered the most critical season for carrot crops, there is often a lack of the product on the market, with a consequent rise in prices (OLIVEIRA et al., 2005). Low temperatures associated with long days induce early bolting. This transition from vegetative to reproductive stage is not interesting for producers (FILGUEIRA, 2008).

The knowledge on adaptation of cultivars to the local climate conditions is important for growing carrots. The cultivars recommended for winter crops are from the Nantes group, which require mild climate and are sensitive to high temperature and precipitation. The cultivars recommended for summer crops are from the Brasilia group (Brasilia, Carandaí, Alvorada and Esplanada), which have adapted to high temperature and precipitation (FILGUEIRA, 2008).

The weather conditions in the different crop seasons and locations may influence the adaptability and stability of cultivars (OLIVEIRA et al., 2005). There are cultivars that form good roots at temperatures from 18 to $25^{\circ} \mathrm{C}$. Temperatures above $30^{\circ} \mathrm{C}$ causes reduced vegetative cycle of plants, affecting the root development and productivity (VIEIRA; PESSOA, 2008). Thus, in most cases, environmental temperature is decisive for choosing a cultivar and for the cultivar adaptation (REGHIN; DUDA, 2000). The development of carrot cultivars with heat tolerance and resistance to the crop major diseases has generated an increase in crop area in regions with warm climates, especially in Northeastern and West-Central Brazil (SILVA et al., 2011).

In the Lower Basin of the São Francisco
Valley, mild temperatures occur from April to September and the hottest from October to March (TEIXEIRA, 2010). Considering these local features, better crop yields are expected in periods of mild temperatures (winter) compared to periods of high temperatures (summer). The average air temperature in this region varies from 24.1 to $28.0^{\circ} \mathrm{C}$, with maximum temperatures from 29.6 to $34.0^{\circ} \mathrm{C}$ and minimum from 18.2 to $22.1^{\circ} \mathrm{C}$. The rainy season is concentrated between November to April, with 90\% of the annual total precipitation, and January to April, contributing with $70 \%$ of the annual total precipitation, standing out March as the most and August as the least rainy month (TEIXEIRA, 2010). The average annual precipitation is $549 \mathrm{~mm}$.

Spacing and planting density recommendations for crops in general have sought to meet specific needs of cultural practices and improve productivity. However, changes in these recommendations induce a series of changes in the plant growth and development requiring adaptations to meet local peculiarities. Regarding planting density, results in studies vary depending on the cultivar and producing region (LOPES et al., 2008).

Spacing ranging from 15 to $30 \mathrm{~cm}$ between rows and 5 to $7 \mathrm{~cm}$ between plants are reported for carrot crops (SOUZA et al., 2002; FILGUEIRA, 2008).

In Uberlândia, State of Minas Gerais (MG), Luz et al. (2009) found yields of 29.6 to $37.8 \mathrm{Mg} \mathrm{ha}^{-1}$ (total) and 20.8 to $28.7 \mathrm{Mg} \mathrm{ha}^{-1}$ (commercial) in an autumn-winter crop, and 7.2 to $34.8 \mathrm{Mg} \mathrm{ha}^{-1}$ (total) and 0.8 to $10.1 \mathrm{Mg} \mathrm{ha}^{-1}$ (commercial) in a summer crop. Reghin; Duda (2000) in a summer crop found yields of 54.3 (total) and $42.9 \mathrm{Mg} \mathrm{ha}^{-1}$ (commercial) for the cultivar Brasilia. Filgueira (2008) found in São Gotardo MG, with appropriated crop conditions (winter), $50.0 \mathrm{Mg} \mathrm{ha}^{-1}$ of root at field conditions, in a soil under native savanna (Cerrado biome), applying liming and mineral fertilization.

In this context, the objective of this work was to evaluate the production of carrots (cultivar Brasilia) in the winter and summer crop seasons, sowed with different spacing between plants in the Lower Basin of the São Francisco Valley.

\section{MATERIAL AND METHODS}

The experiments were conducted from May 2011 to February 2012, in the Bebedouro Experimental Field of the Brazilian Agricultural Research Corporation in Petrolina (Embrapa SemiArid), State of Pernambuco (PE) $\left(09^{\circ} 09^{\prime} \mathrm{S}, 40^{\circ} 22^{\prime} \mathrm{W}\right.$ and $365.5 \mathrm{~m}$ of altitude). The soil was classified as Oxysol (SANTOS et al., 2006), with the following characteristics: $\mathrm{pH}\left(\mathrm{H}_{2} \mathrm{O}\right)=5.9, \mathrm{Ca}^{2+}=24 \mathrm{mmol}_{\mathrm{c}} \mathrm{dm}^{-3}$, $\mathrm{Mg}^{2+}=8 \mathrm{mmol}_{\mathrm{c}} \mathrm{dm}^{-3}, \mathrm{~K}^{+}=3.0 \mathrm{mmol}_{\mathrm{c}} \mathrm{dm}^{-3}, \mathrm{Al}^{3+}=0.2$ $\mathrm{mmol}_{\mathrm{c}} \mathrm{dm}^{-3}$, P (Mehlich) $=5.1 \mathrm{mg} \mathrm{dm}{ }^{-3}$ and Organic Matter $=5.1 \quad \mathrm{~g} \mathrm{~kg}^{-1}, \quad$ sand $=81 \%, \quad$ silt $=11 \% \quad$ and 
clay $=8 \%$. The monthly precipitation, maximum, minimum and average temperatures and air relative humidity in the experiment period are shown in Table 1.

Table 1. Monthly precipitation, maximum, minimum and average temperatures and air relative humidity in the experiment period. Embrapa Semi-Arid.

\begin{tabular}{|c|c|c|c|c|c|}
\hline \multirow{2}{*}{ Months } & \multirow{2}{*}{$\begin{array}{l}\text { Precipitation } \\
\text { (mm) }\end{array}$} & \multicolumn{3}{|c|}{ Temperatures $\left({ }^{\circ} \mathrm{C}\right)$} & \multirow[t]{2}{*}{ Relative Humidity (\%) } \\
\hline & & Maximum & Minimum & Average & \\
\hline \multicolumn{6}{|c|}{ Winter } \\
\hline May & 20.3 & 29.9 & 20.0 & 24.4 & 71.8 \\
\hline June & 5.1 & 30.0 & 18.3 & 23.8 & 66.6 \\
\hline July & 0.3 & 29.2 & 18.0 & 23.4 & 63.4 \\
\hline August & 1.2 & 31.3 & 19.2 & 24.8 & 58.7 \\
\hline Averages & $(26.9)^{*}$ & 30.1 & 18.9 & 24.1 & 65.1 \\
\hline \multicolumn{6}{|c|}{ Summer } \\
\hline October & 0.0 & 35.1 & 22.1 & 28.2 & 48.5 \\
\hline November & 0.0 & 35.9 & 22.9 & 29.1 & 46.2 \\
\hline December & 54.6 & 33.6 & 22.2 & 27.2 & 61.7 \\
\hline January & 86.0 & 33.5 & 22.5 & 27.6 & 58.5 \\
\hline February & 75.9 & 32.1 & 21.4 & 25.9 & 69.8 \\
\hline Averages & $(216.5)^{*}$ & 34.0 & 22.2 & 27.6 & 56.9 \\
\hline
\end{tabular}

*Accumulated values.

A randomized block experimental design was used with treatments arranged in split plot with three replications. The plot consisted of crop seasons (winter and summer) and the subplots of plant spacing $(4,6,8$ and $10 \mathrm{~cm})$, using the cultivar Brasilia for planting.

Soil preparation consisted of plowing and harrowing. The experimental unit consisted of plots of $0.25 \mathrm{~cm}$ plant beds $(2.0 \mathrm{~m}$ long and $1.20 \mathrm{~m}$ wide), with spacing between rows of $20 \mathrm{~cm}$. Sowing was carried out transversally to the beds. The eight centerlines were used for evaluations, removing the two last plants of the row ends. The winter seeding was performed at May 10 and the summer at October 20, 2011. Thinning was performed 25 days after sowing, correcting to the planting density of each treatment.

Planting fertilization consisted of $40 \mathrm{Mg} \mathrm{ha}^{-1}$ of goat manure, $40 \mathrm{~kg} \mathrm{ha}^{-1}$ of nitrogen, phosphorus $400 \mathrm{~kg} \mathrm{ha}^{-1}$ and $60 \mathrm{~kg} \mathrm{ha}^{-1}$ potassium. Topdressing fertilization consisted of $40 \mathrm{~kg} \mathrm{ha}^{-1}$ of nitrogen and $120 \mathrm{~kg} \mathrm{ha}^{-1}$ potassium, divided at 20 and 40 days after emergence (ALVAREZ et al., 1999).

A micro-sprinkler irrigation system was used with water depths of 10 to $11 \mathrm{~mm}$ (winter) and 13 to $14 \mathrm{~mm}$ (summer), applied three times a week, calculated as a function of a class A tank evaporation, according to the crop need (MAROUELLI et al., 2007). No phytosanitary treatments were performed, since the plants presented good vegetative development, without pests and diseases outbreaks during the experiment. Weed control was performed by hoeing up to about 60 days after sowing.

Samples were collected at August 31 (winter) and February 09 (summer), 2012, when the leaves were slightly bent and yellow. The evaluations consisted of plant height in $\mathrm{cm}$ (measured from the ground to the upper leave edge), total yield (total weight of the roots, expressed in $\mathrm{Mg} \mathrm{ha}{ }^{-1}$ ), commercial yield (roots with more than $10 \mathrm{~cm}$ long, free from cracks, bifurcations and mechanical damage, expressed in $\mathrm{Mg} \mathrm{ha}^{-1}$ ) and fresh root weight (total fresh weight per number of commercial roots, expressed in $\operatorname{g~root}^{-1}$ ).

Data were subjected to analysis of variance for each characteristic assessed and their effects evaluated by $\mathrm{F}$ test at $5 \%$ of probability. The averages for planting seasons were compared by Tukey test at $5 \%$ of probability and plant spacing by fitting polynomial regression models, using as criteria for choosing the model the significant effect by the $\mathrm{F}$ test at $5 \%$ of probability and the magnitude of the coefficient of determination, using the software SISVAR 5.0 (FERREIRA, 2011).

\section{RESULTS AND DISCUSSION}

The results showed significant effects in the planting season interaction with spacing between plants for all variables, except for fresh root weight, which showed a significant effect only for spacing.

Plant height showed a linear decrease with increasing spacing in summer from 53.4 to $51.0 \mathrm{~cm}$, and the greater height $(50.7 \mathrm{~cm})$ was found with spacing between plants of $7.96 \mathrm{~cm}$ in winter (Figure 1). Bernardi et al. (2004) found plant heights higher than those, from 56.8 to $61.8 \mathrm{~cm}$ with two cultivars under different planting densities. Generally, high densities result in greater plant heights (RAJASEKARAN et al., 2006). An increased in vegetative growth in summer compared with winter was found, which denotes low adaptation of the plant to this more stressful conditions, which induce vegetative growth rather than root growth (production of assimilates that are translocated to the roots, promoting increased yield). 


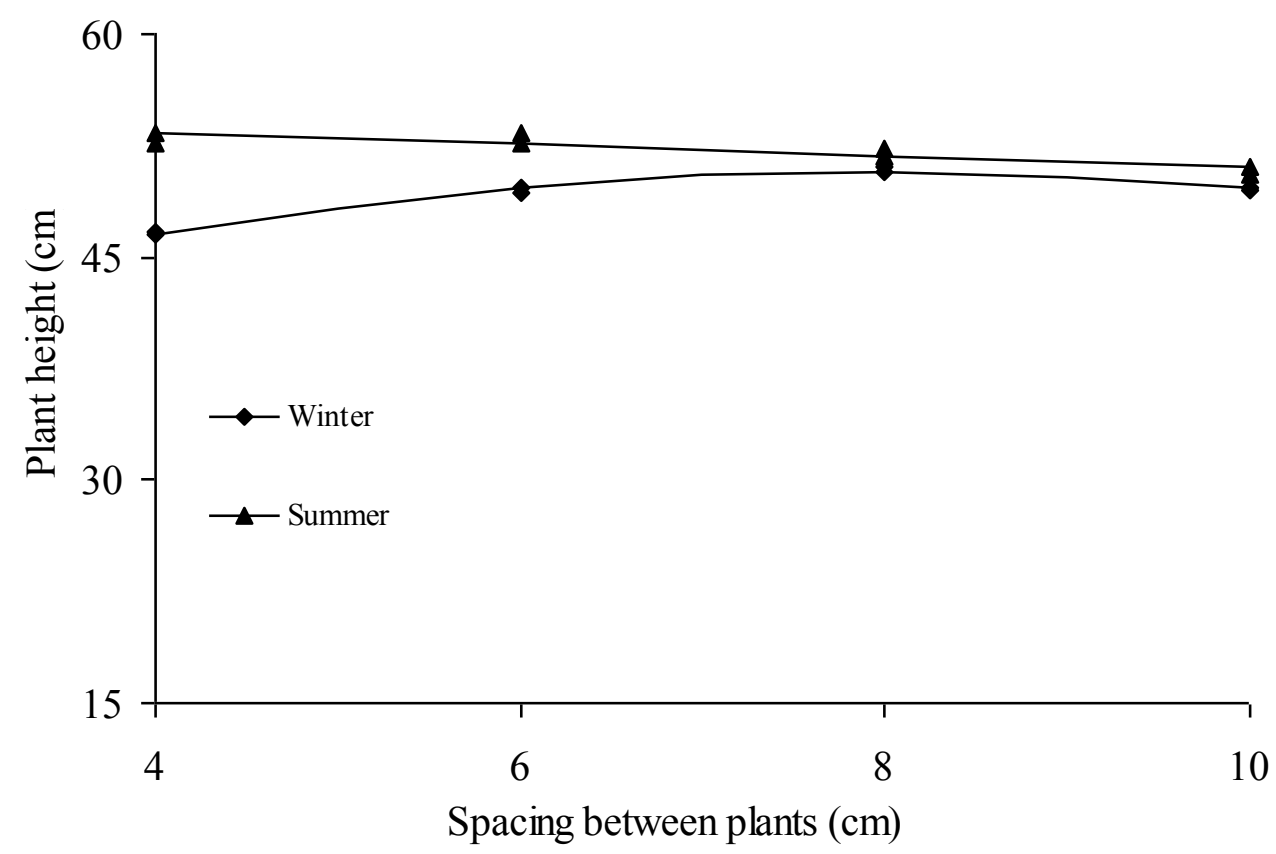

Figure 1. Carrot plant height as a function of planting seasons and spacing between plants. Embrapa Semi-Arid.

Similar results were found for total root yield (Figure 2), which presented negative linear effect to increasing spacing between plants in the summer season. The smallest spacing (4.0) reached $56.6 \mathrm{Mg}$ $\mathrm{ha}^{-1}$ and reduced up to $40.7 \mathrm{Mg} \mathrm{ha}^{-1}$ with the wider spacing between plants $(10 \mathrm{~cm})$. Yield was lower by $28.1 \%$ in the largest spacing compared to the smallest.

In the winter crops, a quadratic effect was found for the total root yield, with minimum yield in the spacing between plants of $10 \mathrm{~cm}\left(46.5 \mathrm{Mg} \mathrm{ha}^{-1}\right)$.
The highest yield was fond in the smaller spacing (4.0 $\mathrm{cm}$ between plants), reaching $73.3 \mathrm{Mg} \mathrm{ha}^{-1}$. Similar results were found in the summer crops. Lopes et al. (2008), evaluating plant spacing of carrots $(4,6$ and $8 \mathrm{~cm})$, found higher carrot yields also with the spacing of $4 \mathrm{~cm}$. Alves et al. (2010) state that this is the best spacing between plants for carrot crops. Luz et al. (2009) found higher total yield in the autumn-winter crop of carrots compared to the summer season.

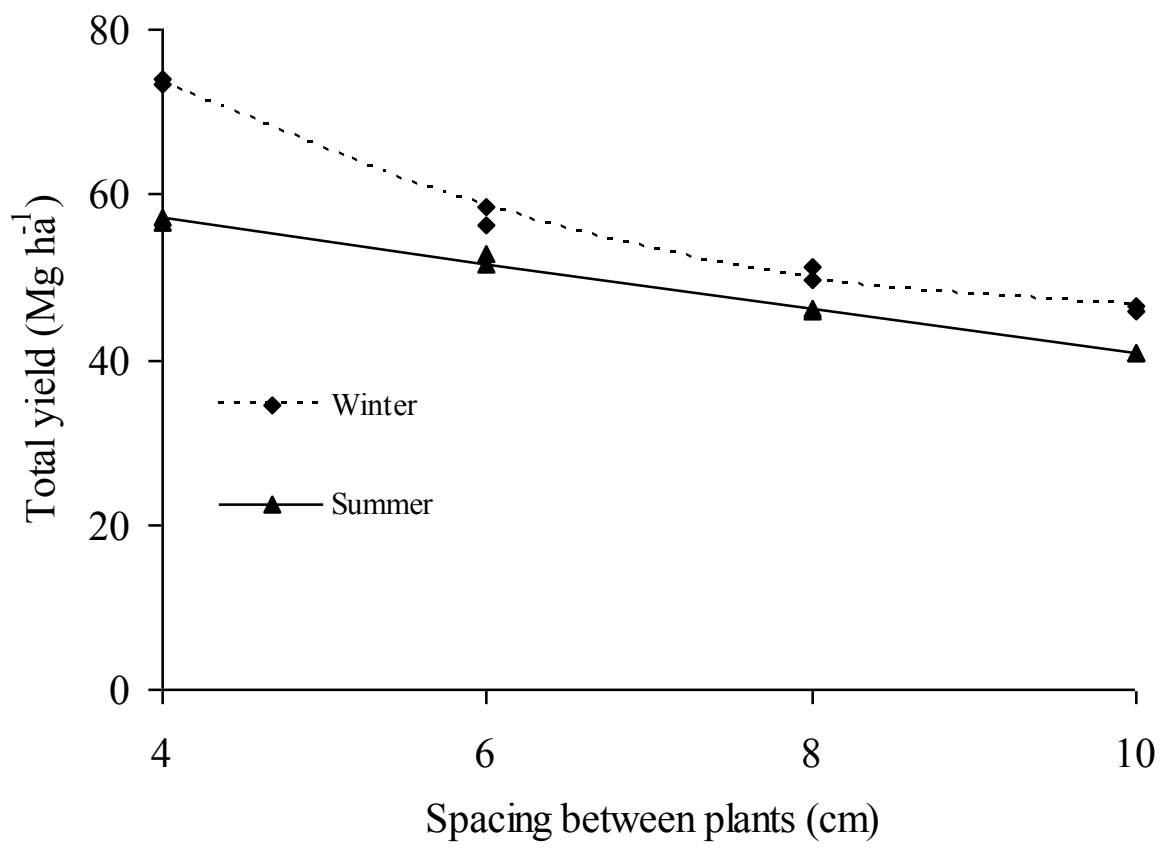

Figure 2. Carrot total yield as a function of planting seasons and spacing between plants. Embrapa Semi-Arid. 
A negative linear effect with increasing spacing between plants were found for commercial yield in two cropping seasons (Figure 3). The lowest yields were found in summer crops and with the widest spacing between plants. The smallest spacing between plants $(4.0 \mathrm{~cm})$ had yield of $45.9 \mathrm{Mg} \mathrm{ha}^{-1}$ in the summer and $63.1 \mathrm{Mg} \mathrm{ha}^{-1}$ in the winter crop, i.e., lower temperatures provided yield $37.5 \%$ higher in the more productive spacing. These results confirm those found by Lopes et al. (2008) and Alves et al.
(2010), which found higher yields with spacing of $4.0 \mathrm{~cm}$. Wider spacing between plants provided lower root yields due to the lower number of plants per hectare. These results suggest that an ideal plant population is needed for proper distribution of photosynthetic radiation in the leaves, increasing the net photosynthetic rate, with consequent increase in root yield. According to Barros Júnior et al. (2005), commercial yield of carrot increases with an increase in population density.

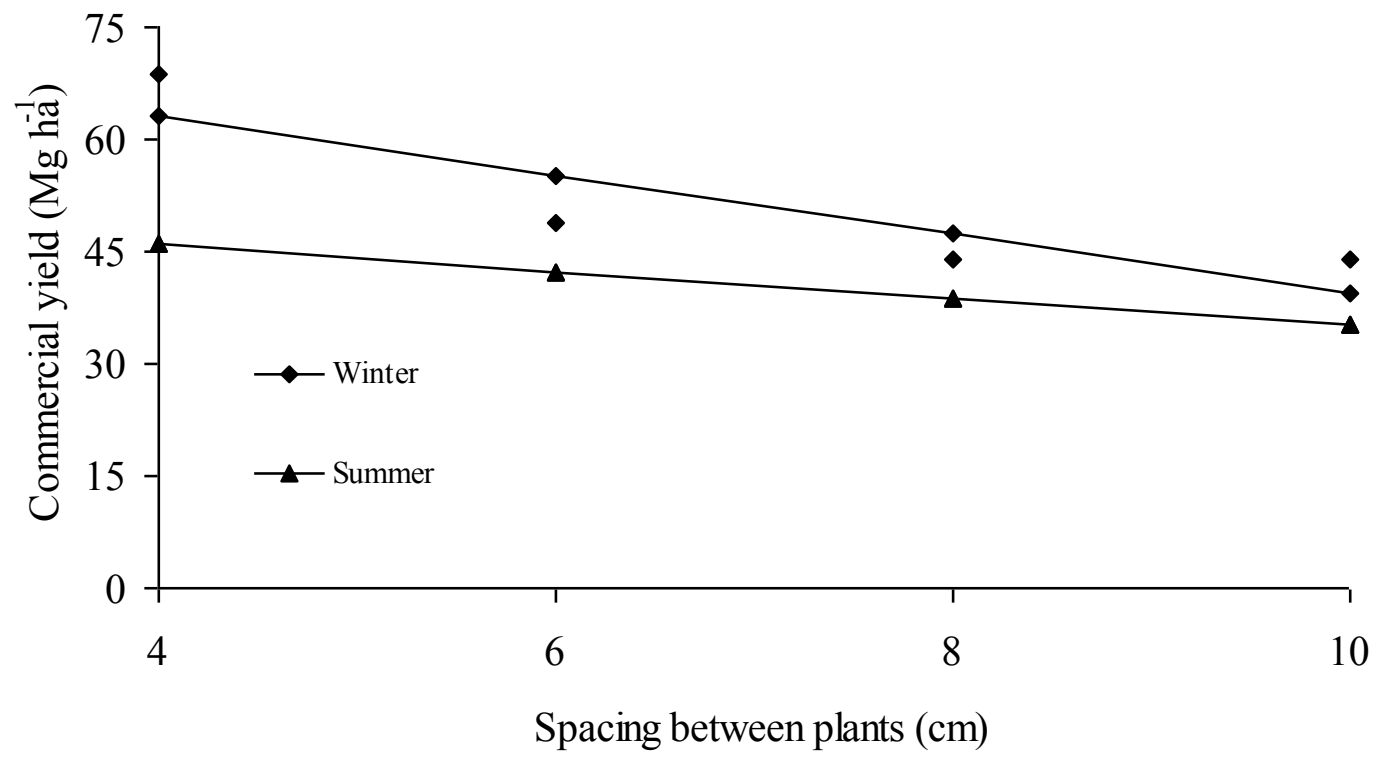

Figure 3. Carrot commercial yield as a function of planting seasons and spacing between plants. Embrapa Semi-Arid.

Local climatic conditions during the experiment in the winter (average temperature of $24.1^{\circ} \mathrm{C}$, minimum of $18.9^{\circ} \mathrm{C}$ and maximum of $30.1^{\circ}$ $\mathrm{C}$, relative humidity of $65.1 \%$ and precipitation of $26.9 \mathrm{~mm}$ ) compared to summer (average temperature of $27.6^{\circ} \mathrm{C}$, minimum of $22.2^{\circ} \mathrm{C}$ and maximum of $34.0^{\circ} \mathrm{C}$, relative humidity of $56.9 \%$ and precipitation of $216.5 \mathrm{~mm}$ ) (Table 1) were essential in reducing the summer crop yield. According to Rubatzky et al. (1999), carrots can grow at temperatures from 4 to $40^{\circ} \mathrm{C}$, however, temperatures between 10 and $25^{\circ} \mathrm{C}$ favor the quality of roots. Temperatures from 18 to $25^{\circ} \mathrm{C}$ are considered ideal for shoot growth. The highest root growth rates are found at temperatures from 18 to $20^{\circ} \mathrm{C}$. Temperatures above $30^{\circ} \mathrm{C}$ reduces the plant vegetative cycle, affecting the root development and productivity (VIEIRA, PESSOA, 2008). Reductions in productivity may also occur in very low temperature (frost), as well as with excessive precipitation in the crop season (FILGUEIRA, 2008).

Regarding fresh root weight (Figure 4), there were significant independent effects for the studied factors. The higher fresh root weight $\left(89.9 \mathrm{~g} \mathrm{root}^{-1}\right)$ was higher in winter crop season compared to the summer $\left(81.4 \mathrm{~g} \mathrm{root}^{-1}\right)$. The spacing between plants had a positive linear effect with an increased in spacing between plants. The smaller spacing between plants $(4.0 \mathrm{~cm})$ reached fresh weight of 70.4 $\mathrm{g} \mathrm{root}^{-1}$ and the spacing of $10 \mathrm{~cm}$ reached $100.9 \mathrm{~g}$ root $^{-1}$ (Figure 4). However, considering the higher number of plants per hectare and the slightly lower fresh weight in the shortest spacing $(4 \mathrm{~cm})$ compared to the spacing of $10 \mathrm{~cm}$, a higher yield was achieved with the smaller spacing. These results confirm those found by Rajasekaran et al. (2006) and Alves et al. (2010), who reported that higher population densities result in lower fresh weight of roots. The results also confirm those found by Lana; Vieira (2000), who found that the use of wider spacing between plants, in general, provides larger and not uniform roots, with high frequency of various strains, with consequent reduction in quality and productivity. Moreover, carrots grown during the hottest period of the year have lower root weight compared to carrots from periods of mild temperatures (LANA; VIEIRA, 2000). 


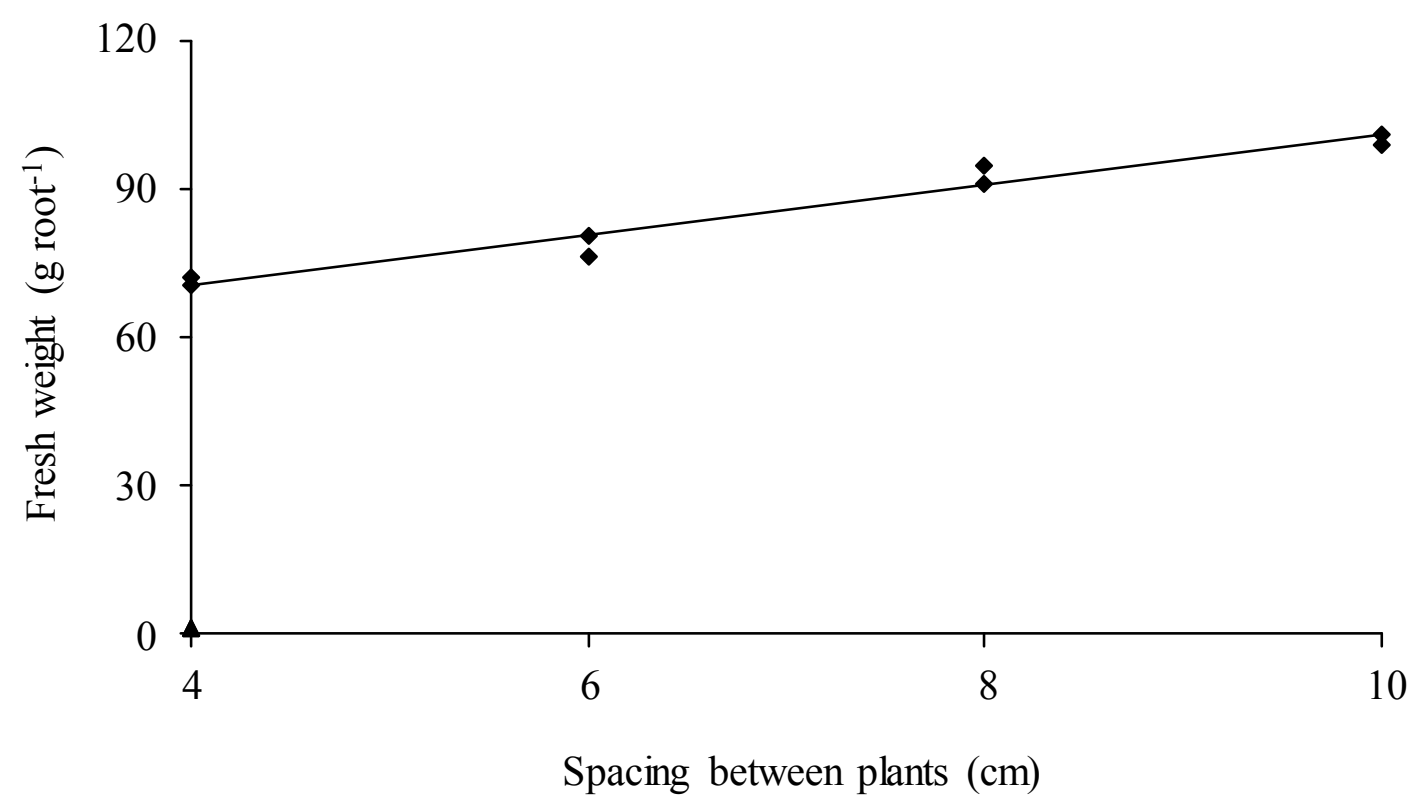

Figure 4. Fresh weight of carrot roots as a function of spacing between plants. Embrapa Semi-Arid.

\section{CONCLUSION}

The spacing of $4.0 \mathrm{~cm}$ between plants is the most recommended for carrots (cultivar Brasilia), regardless of planting season in the Lower Basin of the São Francisco Valley;

The winter season (mild temperatures) presents the best results of production, compared to the summer. Despite provide less productivity, the summer season does not limit the crop of carrots, which may be grown throughout the year in the Lower Basin of the São Francisco Valley.

\section{REFERENCES}

ALVAREZ, V. H. V. et al. Sugestões de adubação para hortaliças. In: RIBEIRO, A. C.; GUIMARÃES, P. T. G.; ALVAREZ, V. V. H. (Eds.). Recomendação para o uso de corretivos e fertilizantes em Minas Gerais: 5. Aproximação. Viçosa: Comissão de Fertilidade do Solo do Estado de Minas Gerais, 1999. p. 171-208.

ALVES, S. S. V. et al. Qualidade de cenouras em diferentes densidades populacionais. Revista Ceres, Viçosa, v. 57, n. 2, p. 218-223, 2010.

BARROS JÚNIOR, A. P. et al. Desempenho agronômico do bicultivo da alface em sistemas consorciados com cenoura em faixa sob diferentes densidades populacionais. Horticultura Brasileira, Brasília, v. 23, n. 3, p. 712-717, 2005.

BERNARDI, V. F. et al. Avaliação de espaçamentos de cenoura para os híbridos AF845 e AF750. Acta
Scientiarum. Agronomy, Maringá, v. 26, n. 2, p. 125-130, 2004.

EMBRAPA HORTALIÇAS - CNPH. Situação das Safras de Hortaliças no Brasil - 2000-2012. Disponível em: <http://www.cnph.embrapa.br> Acesso em: 4 abr. 2014.

FAO. Agricultural production, primary crops. Disponível em: <http://www.fao.org $>$. Acesso em: 8 mar. 2014.

FERREIRA, D. F. Sisvar: a computer statistical analysis system. Ciência e Agrotecnologia, Lavras, v. 35, n. 6, p. 1039-1042, 2011.

FILGUEIRA, F. A. R. Novo manual de olericultura: agrotecnologia moderna na produção e comercialização de hortaliças. 3. ed. Viçosa, MG: Editora UFV, 2008. 421 p.

LANA, M. M.; VIEIRA, J. V. Fisiologia e manuseio pós-colheita de cenoura. Brasília: Embrapa Hortaliças, 2000. 15 p. (Circular técnica, 21).

LOPES, W. A. R. et al. Produtividade de cultivares de cenoura em diferentes densidades de plantio. Revista Ceres, Viçosa, v. 55, n. 5, p. 482-487, 2008.

LUZ, J. M. Q. et al. Desempenho de cultivares de cenoura no verão e outono-inverno em UberlândiaMG. Horticultura Brasileira, Brasília, v. 27, n. 1, p. 96-99, 2009.

MAROUELLI, W. A.; OLIVEIRA, R. A.; SILVA, W. L. C. Irrigação na cultura da cenoura. Brasília: 
Embrapa Hortaliças, 2007. 14 p. (Circular técnica, 48).

OLIVEIRA, C. D.; BRAZ, L. T.; BANZATTO, D. A. Adaptabilidade e estabilidade genotípica de genótipos de cenoura. Horticultura Brasileira, Brasília, v. 23, n. 3, p. 743-748, 2005.

RAJASEKARAN, L. R.; ASTATKIE, T.; CALDWELL, C. Seeding rate and seed spacing modulate root yield and recovery of slicer and dicer carrots differently. Scientia Horticulturae, v. 107, n. 4, p. 319-324, 2006.

REGHIN, M. I.; DUDA, C. Efeito da época de semeadura em cultivares de cenoura. Ciências Exatas e da Terra, Ciência Agrárias e Engenharias, Ponta Grossa, v. 6, n. 1, p. 103-114, 2000 .

RESENDE, F. V. et al. Uso de cobertura morta vegetal no controle da umidade e temperatura do solo, na incidência de plantas invasoras e na produção da cenoura em cultivo de verão. Ciência e Agrotecnologia, Lavras, v. 29, n. 1, p. 100-105, 2005.

RUBATZKY, V. E.; QUIROS, C. F.; SIMON, P. W. Carrots and related vegetable Umbelliferae. Oxon: CABI Publishing. 1999. 304 p.

SANTOS, H. G. et al. Sistema brasileiro de classificação de solos. 2. ed. Rio de Janeiro, RJ: Embrapa Solos, 2006. 306 p.

SILVA, G. O.; VIEIRA, J. V.; NASCIMENTO, W. M. Estratégias de seleção para germinação de sementes de cenoura em altas temperaturas. Semina: Ciências Agrárias, Londrina, v. 32, n. 3, p. 849-854, 2011.

SOUZA, R. J. et al. Cultura da cenoura. Lavras: Editora UFLA, 2002. 68 p. (Textos acadêmicos, 22).

TEIXEIRA, A. H. C. Informações agrometeorológicas do Pólo Petrolina, PE/ Juazeiro - 1963 a 2009. Petrolina: Embrapa Semiárido, 2010. 21 p. (Embrapa Semiárido. Documentos, 233).

VIEIRA, J. V.; PESSOA, H. B. S. V. Cultivares. In: Cenoura. Sistemas de produção, 5. Junho, 2008. Embrapa Hortaliças. Disponível em: <http:// sistemasdeproducao.cnptia.embrapa.br $>$ Acesso em: 11 nov. 2014.

VILELA, N. J.; BORGES, I. O. Retrospectiva e situação atual da cenoura no Brasil. Brasília: Embrapa Hortaliças, 2008. 9 p. (Circular Técnica, 59). 